\title{
MODEL MATEMATIK HUBUNGAN LUAS LAHAN DENGAN JUMLAH POPULASI TERNAK SAPI BALI DI PROVINSI BALI
}

\author{
SUKADA, I K., I G. SUARTA, DAN I N. W. PARIMARTHA \\ Fakultas Peternakan Universitas Udayana Denpasar Bali \\ e-mail: ketut_sukada888@yahoo.com
}

\begin{abstract}
ABSTRAK
Penelitian ini dilakukan untuk mengetahui sejauh mana hubungan perkembangan populasi sapi bali di Bali terhadap luas lahan pertanian. Untuk mendapatkan data yang representative mewakili Bali maka sampling dilakukan di berbagai Kabupaten Kota (BPS). Data dianalisis dengan beberapa model regresi yaitu regresi polinomial, regresi exponensial, regresi logaritmik dan Hoerl's regresi. Data diolah dengan Costat. Hasil penelitian menunjukkan bahwa melalui model regresi polinomal didapatkan bahwa hubungan luas lahan terhadap populasi sapi bali berhubungan positif sangat nyata $(\mathrm{P}<0,05) \mathrm{R}^{2}=0.6696$ dan Mode persamaan matematika $\mathrm{Y}=9.426+1,1061 \mathrm{X}$. Melalui model regresi exponensial didapatkan bahwa hubungan luas lahan terhadap populasi sapi bali berhubungan positif sangat nyata $(\mathrm{P}<0,05) \mathrm{R}^{2}=0,6580$ dan model persamaan matematika $\mathrm{Y}=14,0396 \mathrm{e}^{0,0278}$. (3). Melalui model regresi logaritmik didapatkan bahwa hubungan luas lahan terhadap populasi sapi bali berhubungan positif nyata $(\mathrm{P}<0,05)$ $\mathrm{R}^{2}=0,5867$ dan model persamaan matematika $\mathrm{Y}=-35,1095+25,9318 \mathrm{Ln}(\mathrm{X})$ dan (4). Melalui Hoerl's didapatkan bahwa hubungan luas lahan terhadap populasi sapi bali berhubungan positif sangat nyata $(\mathrm{P}<0,05) \mathrm{R}=0,8923$ dan model persamaan matematika $\mathrm{Y}=2,5042 \mathrm{X}^{\mathrm{0}, 8504} \mathrm{e}^{-0,0017}$. Dari ke empat model yang dicoba disimpulkan bahwa semua menunjukkan bahwa model hubungan fungsi matematika antara luas kepemilikan lahan terhadap jumlah populasi sapi bali menunjukkan hubungan yang positif significant sampai sangat significant $(\mathrm{P}<0,05)$ dengan demikian alih fungsi lahan pertanian di Bali mengakibatkan luas lahan peternakan berkurang dan dapat membahayakan poulasi sapi bali.
\end{abstract}

Kata kunci: modling matematika, populasi sapi bali, luas lahan, alih fungsi lahan

\section{MATHEMATICS MODELING RELATIONSHIP LAND LENGTH WITHIN BALI CATTLE POPULATION IN BALI}

\begin{abstract}
This study was interested to know the relationship of bali cattle population in Bali to the land of agriculture. In order to obtain a representative data, the sampling was conducted in various District Municipality (BPS). The data was analyzed by using multiple regression models, such as: regression polynomial, regression exponential, logarithmic and Hoerl's regression. The data were processed with Costat Statistics. It showed that through polinomal regression models, land size was significantly related to cattle population $(\mathrm{P}<0.05) \mathrm{R} 2=0.6696$ and math model equation $\mathrm{Y}=9426+1,1061 \mathrm{X}$; Exponential regression models land area of Bali cattle population was positively related significant $(\mathrm{P}<0.05) \mathrm{R} 2=0.6580$ and math model equation $\mathrm{Y}=14.0396$ e 0.0278 ; Logarithmic model showed that the relationship to the land area of bali cattle population was positively associated $(\mathrm{P}<0.05) \mathrm{R} 2$ $=0.5867$ and math model equation $\mathrm{Y}=-35.1095+25.9318 \mathrm{Ln}(\mathrm{X})$; and Hoerl's found relationship to the land area of bali cattle population positively related to highly significant $(\mathrm{P}<0.05) \mathrm{R}=0.8923$ and math model equation $\mathrm{Y}=$ $2.5042 \mathrm{X}^{0,8504} \mathrm{e}^{-0.0017}$. It can be concluded that using four modeling mathematical functions between the land size ownership with total population of Bali cattle tenure showed positive relationship significant to highly significant $(\mathrm{P}<0.05)$, so agricultural land conversion in Bali reduce farm land area and could threaten Bali cattle population.
\end{abstract}

Keywords: modeling mathematics, bali cattle population, land area, transformation of land

\section{PENDAHULUAN}

Implikasi alih fungsi lahan pertanian yang tidak terkendali dapat mengancam kapasitas penyediaan pangan, dan bahkan dalam jangka panjang dapat menimbulkan kerugian sosial (Iqbal dan Sumaryanto, 2007). Dampak alih fungsi lahan sawah ke penggunaan non pertanian menyangkut dimensi yang sangat luas. Hal itu terkait dengan aspek-aspek perubahan orientasi ekonomi, sosial, budaya, dan politik masyarakat. Arah 
perubahan ini secara langsung atau tidak langsung akan berdampak terhadap pergeseran kondisi ekonomi, tata ruang pertanian, serta prioritas-prioritas pembangunan pertanian wilayah dan nasional (Winoto, 1995; Nasoetion dan Winoto, 1996). Perubahan penggunaan lahan dapat terjadi karena adanya perubahan rencana tata ruang wilayah, adanya kebijakann arah pembangunan dan karena mekanisme pasar. Dua hal terakhir terjadi lebih sering pada masa lampau karena kurangnya pengertian masyarakat maupun aparat pemerintah mengenai tata ruang wilayah. Alih fungsi dari pertanian ke nonpertanian terjadi secara meluas sejalan dengan kebijaksanaan pembangunan yang menekankan kepada aspek pertumbuhan melalui kemudahan fasilitas investasi, baik kepada investor lokal maupun luar negeri dalam penyediaan tanah (Widjanarko, dkk, 2006).

Pertumbuhan penduduk yang cepat diikuti dengan kebutuhan perumahan menjadikan lahanlahan pertanian berkurang di berbagai daerah. Lahan yang semakin sempit semakin terfragmentasi akibat kebutuhan perumahan dan lahan industri. Petani lebih memilih bekerja di sektor informal dari pada bertahan di sektor pertanian. Daya tarik sektor pertanian yang terus menurun juga menjadikan petani cenderung melepas kepemilikan lahannya. Pelepasan kepemilikan lahan cenderung diikuti dengan alih fungsi lahan (Gunanto, 2007).

Pertumbuhan perekonomian menuntut pembangunan infrastruktur baik berupa jalan, bangunan industri dan pemukiman. Kondisi demikian mencerminkan adanya peningkatan permintaan terhadap lahan untuk penggunaan nonpertanian mengakibatkan banyak lahan sawah, terutama di sekitar perkotaan mengalami alih fungsi. Fenomena ini dapat mengakibatkan kerawanan pangan yang pada gilirannya akan mengancam kestabilan nasional (Ilham, dkk, 2003). Bali yang menitik beratkan pengembangan sektor pariwisata akan menambah beban menjadi ancaman bagi sektor peternakan dalam hal perebutan lahan.

Tabel 1. Luas Lahan dan Populasi Ternak Sapi tiap Kabupaten, Kota di Provinsi Bali

\begin{tabular}{lcc}
\hline \multicolumn{1}{c}{ Kabupaten } & Luas Lahan & Jumlah Sapi \\
\hline Jembrana & 32,643 & 36,081 \\
Tabanan & 62,455 & 47,808 \\
Badung & 28,465 & 36,662 \\
Gianyar & 27,250 & 40,420 \\
Kelungkung & 23,175 & 33,958 \\
Bangli & 36,371 & 74,327 \\
Karangasem & 60,891 & 109,48 \\
Buleleng & 81,296 & 92,953 \\
Denpasar & 3,0220 & 6,4510 \\
\hline
\end{tabular}

\section{MATERI DAN METODE}

Data penelitian menggunakan luas kepemilikan lahan dalam satuan hektar dan jumlah populasi ternak sapi bali dalam ekor (BPS Bali 2014). Analisis statistik membandingkan model 4 buah model regression antara lain: (1) Polinomial Regression, (2). Exponential Regression, (3) Logaritmic Regression dan 4. Horls Regression. Untuk mencari model matematika yang terbaik dalam mendapatkan hubungan antara luas lahan dengan populasi ternak sapi bali di provinsi Bali. Analisa regresi merupakan metode statistik untuk menyelidiki dan memodelkan antara satu variabel respon Y dengan satu atau lebih variabel prediktor. Misalnya diberikan himpunan data $\left\{\left(\mathrm{x}_{\mathrm{i}}, \mathrm{y}_{\mathrm{i}}\right)\right\}, \mathrm{I}=1, \ldots$. Secara umum hubungan antara $\mathrm{y}$ dan $\mathrm{x}$ dapat ditulis sebagai berikut: $\mathrm{Y}_{\mathrm{i}}=\mathrm{m}\left(\mathrm{X}_{\mathrm{i}}\right)+\epsilon_{\mathrm{i}}$ dengan $\mathrm{m}\left(\mathrm{X}_{\mathrm{i}}\right)$ adalah suatu fungsi regresi yang belum diketahui dan ingin ditaksir, dan $\epsilon_{\mathrm{i}}$ adalah suatu variabel acak yang menggambarkan variasi Y disekitar m (X) (Hardle 1990).

Data yang diperoleh dalam penelitian ini dianalisis dengan sidik ragam menggunakan berbagai macam analisis regresi baik linear maupun nonlinear antara lain: Polynomial Regression, Exponensial Regression, Logarithmic Regression dan Horl's Regression. Pengolahan data menggunakan Costat.

\section{HASIL DAN PEMBAHASAN}

Dari keempat model yang digunakan untuk menduga nilai regressi didapatkan sebagai berikut:

1. Model regresi polinomial didapatkan nilai $\mathrm{R}^{2}=$ o,6696 menunjukkan hubungan positif yang sangat signifikan $(\mathrm{P}<\mathrm{O}, \mathrm{O} 1)$ dengan model matematika $\mathrm{Y}=9,42638+1,106145532$.

2. Model Regresi Exponensial didapatkan nilai $\mathrm{R}^{2}=0,6580584$ menunjukan hubungan positif yang sangat signifikan $(\mathrm{P}<0,01)$ dengan model matematika $\mathrm{Y}=14,039623 \mathrm{e}^{\mathrm{O}, 0278506}$.

3. Model regresi logaritmik didapatkan $\mathrm{R}^{2}=$ o,5866632424 menunjukkan hubungan yang positif signifikan $(\mathrm{P}<0,05)$ dengan model matematika $\mathrm{Y}=$ $-35,1095+25,931882 \operatorname{Ln}(\mathrm{X})$.

4. Model Horl's regresi didapatkan $\mathrm{R}^{2}=0,8922697364$ menunjukkan hubungan positif yang sangat signifikan $(\mathrm{P}<0,01)$ dengan model matematika $\mathrm{Y}=$ $2,50421 \mathrm{X}^{0,8504558}+\mathrm{e}^{-0,00176 \mathrm{x}}$

Keempat model regresiyang dicobakan menunjukkan hasil yang cukup baik karena menunjukkan nila $\mathrm{R}^{2}$ yang cukup besar, positif dan signifikan antara hubungan kepemilikan luas lahan dan populasi ternak sapi Bali. Hasil ini memberikan gambaran bahwa alih fungsi 


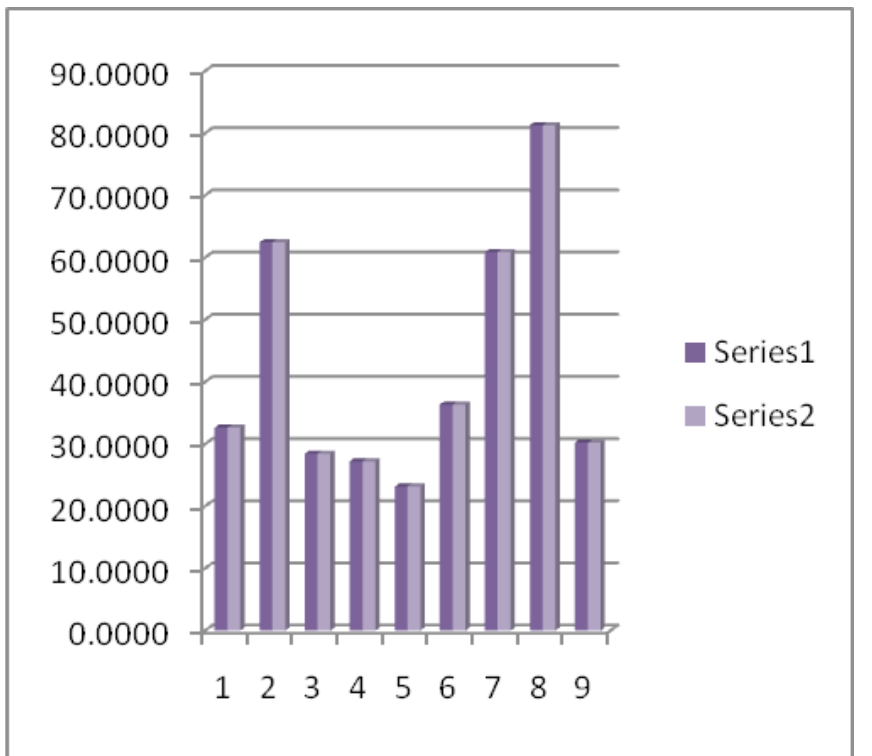

Gambar 1. Histogram Hubungan Luas Lahan dengan Populasi ternak Sapi Bali di Provinsi Bali.

lahan berhubungan sangat erat dengan jumlah populasi ternak sapi bali. Dalam kondisi ini digambarkan bahwa peternakan sapi bali di Provinsi Bali mendapat ancaman yang cukupseriusyangmembahayakanyangmengancam keberlanjutannya jika pemerintah, akademisi maupan seluruh stakeholder yang terlibat tidak dengan segera mencari solusi untuk menyelamatkan alih fungsi lahan yang semakin serius mengancam perkembangan dunia peternakan. Alih fungsi lahan peternakan menjadi fungsi yang lain sudah jelas karena kekalahan bersaing sektor peternakan dengan sektor lain dalam mensejajarkan diri dalam memberikan keuntungan sehingga para pemodal tidak begitu tertarik menanam modalnya untuk mengembangkan sektor peternakan termasuk pula masyarakat petani dan peternak kurang tertarik mengembangkan peternakannya, karena lebih cendrung beralih kesektor lain yang dianggap menjanjikan. Seandainya peternakan sapi bali menemukan cara yang jitu yang mampu mensejajarkan diri dalam memberikan profit dengan sektor lain maka para petani tidak akan mungkin menjual tanahnya beralih ke sektor lain.

\section{SIMPULAN}

Dari penelitian ini dapat disimpulkan bahwa model matematika hubungan luas lahan pertanian dengan populasi sapi bali di Provinsi Bali memiliki hubungan yang positif sangat signifikan. Dari keempat model regresi yang dicobakan semuanya menunjukkan persamaan bahwa luas lahan dan populasi sapi bali berhubungan positif yang sangat signifikan. Dipandang dari sudut besarnya koefisien regresI yang didapatkan, model Horl's didapatkan $\mathrm{R}^{2}=0,8922697364$ menunjukkan hubungan positif yang sangat signifikan dengan model matematika $\mathrm{Y}=2,50421 \mathrm{X}^{0,8504558}+\mathrm{e}^{-0,00176 \mathrm{x}}$

\section{DAFTAR PUSTAKA}

Gunanto, E.S., 2007. Konversi Lahan Pertanian Mengkhawatirkan. Diakses dari http://www.tempointeraktif.com

Hardle. 1990. Metode Estimate. Nadaraya Watson model regresi parametric

Ilham, dkk. 2003. Perkembangan dan Faktor-Faktor yang Mempengaruhi Konversi Lahan Sawah Serta Dampak Ekonominya. IPB Press. Bogor

Iqbal, M dan Sumaryanto. 2007. Strategi Pengendalian Alih Fungsi Lahan. Pertanian Bertumpu Pada Partisipasi Masyarakat. Pusat Analisis Sosial. Ekonomi.

Nasoetion, L,I, dan Winoto, J. 1996. Masalah alih fungsi lahan pertanian dan dampaknya terhadap keberlangsungan swasembada pangan

Syahyuti, 2007. Kebijakan Lahan Abadi untuk Pertanian Sulit Diwujudkan. Diakses dari http://www.litbang. deptan.go.id)

Widjanarko, dkk, 2006. Aspek Pertahanan dalam Pengendalian Alih Fungsi Lahan Pertanian (Sawah). Prosiding Seminar Nasional Multifungsi Lahan Sawah : 22-23. Pusat Penelitian dan Pengembangan BPN. Jakarta

Winoto, J. 1995. Impacts of urbanization on agricultural development in the Northern Coastal Region of West Java. Michigan State University and University Microfilm, Inc., USA 